Original Research

\title{
Pembuatan Water Kefir dengan Memanfaatkan Madu dan Okra (Abelmoschus esculentus)
}

\author{
Oraldo Emeraldi Anggoro ${ }^{1}$, Ruth Chrisnasari ${ }^{1}$, Ardhia Deasy Rosita Dewi ${ }^{1 *}$ \\ ${ }^{1}$ Jurusan Biologi, Fakultas Teknobiologi, Universitas Surabaya, Surabaya-Indonesia \\ * corresponding author: deasyardhia@staff.ubaya.ac.id
}

\begin{abstract}
Okra is one of vegetable that rarely used by Indonesian people, whereas it is healthty because of its high antioxidant and fiber content. Water kefir is a fermented product that used fruit and vegetables as its substrate. This study aims to determine the type of okra treatment (soaked and juiced) and honey concentration $(0 \%, 4 \%$ and $8 \%$ ) on physicochemical, microbiology and organoleptic characteristics of water kefir. This study used a randomized group design method with variations on okra treatment and concentration of honey. Based on the results of physicochemical tests, okra treatment and honey concentration have an interaction and significantly influence the parameters of total sugar, total dissolved solids, lactic acid levels, total acid, $\mathrm{pH}$, antioxidant activity, ethanol levels, total $L A B$ and total yeast. Organoleptic test showed okra treatment and concentration of honey significantly influence the parameters of color, flavor, taste and aftertaste. Soaked okra kefir with $8 \%$ honey is the best result using the effectiveness index based on psycochemical and organoleptic test. The best treatment has a characteristic product of light yellow, less acidic aroma, quite sweet taste, less alcoholic taste and not bitter aftertaste.
\end{abstract}

Keywords: okra, water kefir, honey

Abstrak-Okra merupakan salah satu jenis sayuran yang sangat jarang dimanfaatkan oleh masyarakat Indonesia, padahal okra sangat baik untuk kesehatan tubuh karena okra memiliki kandungan antioksidan dan serat yang tinggi. Water kefir merupakan produk fermentasi yang menggunakan buah dan sayur sebagai substratnya. Penelitian ini bertujuan untuk mengetahui jenis perlakuan okra (rendam dan jus) dan konsentrasi madu (0\%, 4\% dan $8 \%$ ) terhadap karakteristik fisikokimia, mikrobiologi dan organoleptik water kefir. Penelitian inimenggunakan rancangan acak kelompok dengan variasi okra dan variasi konsentrasi madu. Berdasarkan hasil uji fisikokimia, variasi perlakuan okra dan konsentrasi madu memiliki interaksi dan pengaruh terhadap parameter gula total, total padatan terlarut, kadar asam laktat, total asam, $\mathrm{pH}$, aktivitas antioksidan, kadar etanol, total BAL dan total yeast water kefir okra madu. Hasil uji organoleptik menunjukkan ada pengaruh variasi perlakuan okra dan konsentrasi madu terhadap parameter warna, aroma, rasa dan aftertaste. Water kefir okra rendam $8 \%$ merupakan perlakuan terbaik dengan menggunakan metode indeks efektivitas dari hasil uji fisikokimia dan organoleptik. Perlakuan terbaik tersebut memiliki karakteristik warna kuning muda, aroma yang kurang asam, rasa yang cukup manis, rasa yang kurang beralkohol dan aftertaste yang tidak pahit.

Kata kunci: okra, water kefir, madu

\section{PENDAHULUAN}

Pada zaman modern ini, produk minuman fermentasi banyak dikenal masyarakat luas karena manfaatnya bagi kesehatan. Produk minuman fermentasi dibuat dengan cara menambahkan mikroorganisme yang menghasilkan asam organik sehingga menimbulkan rasa asam yang menjadi ciri khas dari minuman fermentasi. Salah satu produk minuman fermentasi adalah kefir. Kefir belum dikenal luas oleh masyarakat Indonesia. Padahal, produk minuman fermentasi tersebut memiliki manfaat yang baik untuk tubuh dan tidak kalah dengan produk minuman fermentasi lain seperti yoghurt, kombucha dan lain-lain. Kefir merupakan kumpulan bakteri Streptococcus sp., Lactobacilli dan beberapa jenis ragi/khamir nonpatogen. Bakteri dalam biji kefir berperan untuk menghasilkan asam laktat dan membentuk rasa. Ragi menghasilkan gas karbondioksida dan sedikit alkohol sehingga menghasilkan rasa asam dan kombinasi dengan rasaalkohol (Usmiati, 2007).

Ada 2 macam jenis minuman fermentasi kefir, yaitu kefir susu (Farnworth \& Mainville, 2008) dan water kefir (Gulitz, et al., 2011). Kefir susu biasanya dibuat dari susu sapi sedangkan water kefir dibuat dari larutan sukrosa dan buah- buahan segar (Gulitz, et al., 2011). Water kefir memiliki keunggulan dibandingkan kefir susu, yaitu kandungan lemak yang lebih rendah (Mubin, 2016). Water kefir dapat dibuat dari berbagai macam buah dan sayuran salah satunya adalah okra.

Okra merupakan salah satu sayuran yang sangat rendah kalori dan tidak mengandung lemak jenuh atau kolesterol. Okra dikenal akan kandungan antioksidannya yang tinggi yang dapat mencegah oksidasi kolesterol jahat oleh radikal bebas (Rossetto, et al., 2002). Di 
Indonesia, okra biasanya hanya dimanfaatkan sebagai sayuran tumis. Okra banyak dikenal di Indonesia karena dapat menstabilkan kadar gula darah bagi penderita diabetes. Kandungan seratnya yang tinggi tersebut menyebabkan okra dapat menurunkan kadar gula darah untuk penderita diabetes (Sabitha, et al.., 2011). Pada percobaan ini, digunakan dua jenis perlakuan okra yaitu dengan cara direndam dan dihancurkan menggunakan blender. Perlakuan rendam bertujuan untuk mengetahui apakah senyawa terlarut dalam okra dapat dimanfaatkan oleh mikroorganisme untuk proses fermentasi, sedangkan perlakuan jus bertujuan untuk mengetahui apakah seluruh komponen okra dapat dimanfaatkan oleh mikroorganisme untuk proses fermentasi. Okra termasuk golongan sayuran yang memiliki rasa pahit sehingga perlu ditambahkan pemanis untuk menutupi cita rasa dari okra. Pemanis yang digunakan dalam pembuatan water kefir kali ini adalah madu.

Madu dipilih karena dikenal memiliki kandungan antioksidan yang tinggi. Selain itu, madu mengandung banyak gula-gula sederhana sehingga diharapkan mikroorganisme dapat lebih mudah mengubah gula tersebut menjadi produk lain seperti asam laktat dan alkohol. Kadar gula yang terkandung dalam madu mencapai $95-99 \%$ terdiri dari fruktosa $(38,2 \%)$, glukosa $(31,3 \%)$, dan jenis gula lain seperti maltosa, sukrosa, isomaltosa, dan beberapa oligosakarida dalam jumlah sedikit. (Nyimas, 2014). Madu memiliki banyak manfaat bagi kesehatan, di antaranya sebagai antibakteri, antioksidan dan mengandung banyak vitamin seperti Thiamin, Riboflavin dan Niacin. Madu juga memiliki aktivitas antimikroba karena madu mengandung flavonoid dan memiliki mekanisme antibakteri yang terdiri dari tekanan osmosis madu, keasaman dan adanya senyawa inhibine (Nyimas, 2014).

Penelitian ini menggunakan dua jenis variasi yaitu pada perlakuan okra (rendam dan jus) dan konsentrasi madu $(0 \%, 4 \%, 8 \%)$. Melalui penelitian ini, penulis ingin mengetahui pengaruh dan interaksi antara perlakuan okra dan konsentrasi madu terbaik sehingga didapatkan hasil uji fisiokimia terbaik dan cita rasa yang paling disukai

\section{METODE}

Alat

Alat yang digunakan pada penelitian kali ini adalah labu ukur (Pyrex), gelas ukur (Pyrex), gelas beaker (Pyrex), Erlenmeyer (Pyrex), kompor (Maspion), timbangan analitik (Adventure OHAUS), waterbath (Hol E4 HH-4), Kulkas (SHARP), blender (Philips), inkubator (YIH DER LM-595D), panci, saringan tahu, pengaduk kaca, cawan petri, ose, spreader, colony counter, refraktometer, autoklaf, mikropipet (BioRad), tip, kuvet plastik, pH meter (Eutech Instrument), spektrofotometer (Genesys $105 \mathrm{UV}$-Vis) dan centrifuge (Hettich Zentrifugen Universal 320R).

Bahan yang digunakan dalam penelitian kali ini adalah kefir grain (Laboratorium Bionutrisi dan Inovasi Pangan), okra (Chicco Swalayan), madu randu (Madu Hutan Wildbee), air (Pure It), NaCl (Merck), reagen DNS (Aldrich), de Mann Rogosa Agar (Himedia), Rochelle's salt (Merck), akuades, spiritus, etanol 70\%,reagen DPPH (Aldrich), $\mathrm{H}_{2} \mathrm{SO}_{4}$ pekat (Mallincordkt), $\mathrm{NaOH}$, indikator PP $1 \%, \mathrm{CuSO}_{4}$ (Merck), reagen PHF (Merck), fenol (Merck), media Hektoen Agar (Merck), media Lactose Broth (Merck), media Bismulth Sulfite Agar (Merck), media Xylose Lysine Deoxycholate (Merck), media Brilliant Green, Lactose Bile (Merck), kertas saring dan aluminium foil (Reynold Wrap Heavy Duty).

\section{Parameter Pengujian dan Variabel Penelitian}

Parameter pengukuran pada water kefir okra madu ini adalah pengukuran fisikokimia yaitu uji warna, kadar gula total, gula reduksi, etanol, asam laktat, $\mathrm{pH}$,total asam dan aktivitas antioksidan, total mikroba dan yeast dengan metode angka lempeng total, dan uji organoleptik terhadap 30 orang panelis agak terlatih. Pada setiap uji, dilakukan pengulangan sebanyak 3 kali. Variabel dalam penelitian ini ada dua yaitu okra yang dihancurkan dengan blender dan okra yang direndam dalam air selama 24 jam serta konsentrasi madu sebesar $0 \%$, $4 \%$, dan $8 \%$. 


\section{Persiapan Okra}

Okra dibuat dengan dua jenis perlakuan berbeda yaitu okra dengan perlakuan jus dan direndam dalam air selama 24 jam. Pertama-tama okra dicuci bersih, lalu dipotong kecil-kecil. Setelah itu, ditambahkan air dengan perbandingan 1:10 dan dicampurkan lalu diblender. Okra kemudian disaring menggunakan kain saring dan dipisahkan dalam beberapa wadah. Setelah itu, madu ditambahkan dengan variasi konsentrasi yaitu $0 \%, 4 \%$ dan $8 \%$ pada setiap wadah. Selanjutnya dilakukan pasteurisasi pada suhu $85^{\circ} \mathrm{C}$ selama 2 menit (Sabil, 2015), lalu didinginkan hingga mencapai suhu ruang.

Pada variabel kedua yaitu pertama-tama okra dicuci bersih, lalu dipotong kecil-kecil. Setelah itu, direndam dalam air dengan perbandingan 1:10, lalu diinkubasi selama 24 jam. Setelah itu, dipisahkan dalam beberapa wadah lalu ditambahkan variasi konsentrasi madu yaitu $0 \%, 4 \%$ dan $8 \%$. Selanjutnya dilakukan pasteurisasi pada suhu $85^{\circ} \mathrm{C}$ selama 2 menit (Sabil, 2015), lalu didinginkan hingga mencapai suhu ruang.

\section{Pembuatan Water Kefir Okra Madu}

Okra yang telah disiapkan sebelumnya, ditambahkan madu dengan konsentrasi $0 \%, 4 \%$ dan $8 \%$. Campuran tersebut dipasteurisasi pada suhu $85^{\circ} \mathrm{C}$ selama 2 menit, lalu didinginkan sampai mencapai suhu ruang. Kemudian ditambahkan butir-butir kefir grain sebanyak $10 \%$ $(\mathrm{b} / \mathrm{v})$, lalu diinkubasi pada suhu ruang selama $24 \mathrm{jam}$.

\section{Metode Analisis Data}

Penelitian ini dilakukan menggunakan metode rancangan acak kelompok, data yang diperoleh akan dianalisis menggunakan software yaitu program Minitab. Pada penelitian kali ini terdapat dua jenis data, yaitu data parametrik dan data non-parametrik. Untuk data parametrik akan dilakukan uji normalitas dan homogenitas terlebih dahulu untuk mengetahui apakah populasi berdistribusi normal atu tidak. Selanjutnya data akan diolah menggunakan metode two way ANOVA jika data berdistribusi normal dan homogen. Jika hasil statistik menunjukkan perbedaan signifikan dengan $\alpha=0,05$, maka akan dilakukan analisis multiple comparison dengan metode Tukey. Sedangkan data non-parametrik akan diolah menggunakan metode Friedman. Untuk menentukan hasil terbaik dariperlakuan water kefir okra, maka digunakan metode Indeks Efektivitas.

\section{HASIL DAN BAHASAN}

\section{Uji Kimiawi Water Kefir Okra Madu}

\section{a. Gula Total}

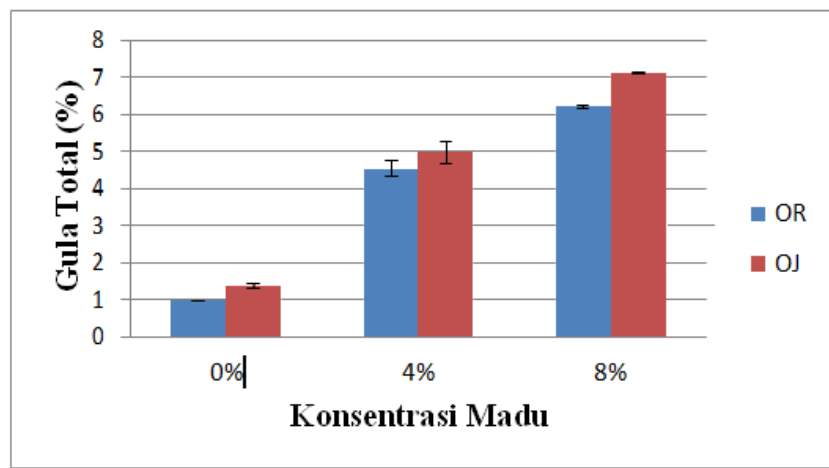

Gambar 1. Hasil uji gula total $\left(\mathrm{T}_{24}\right)$ water kefir okra madu keterangan: OR $\rightarrow$ okra rendam OJ $\rightarrow$ okra jus.

Hasil uji statistik menunjukkan variasi perlakuan okra berpengaruh terhadap parameter gula total. Hal ini mungkin terjadi karena saat okra dihancurkan menggunakan blender, kandungan gula dalam okra lebih terlarut merata di dalam air dibandingkan dengan perlakuan 
rendam. Komponen karbohidrat utama okra tediri dari galaktosa, rhamnosa dan asam galakturonat (Kumar et al., 2009). Variasi konsentrasi madu juga berpengaruh terhadap kadar gula total. Hal tersebut dikarenakan kadar gula yang terkandung dalam madu mencapai 9599\% yang sebagian besar terdiri atas fruktosa dan glukosa (Nyimas, 2014).

\section{b. Gula Reduksi}

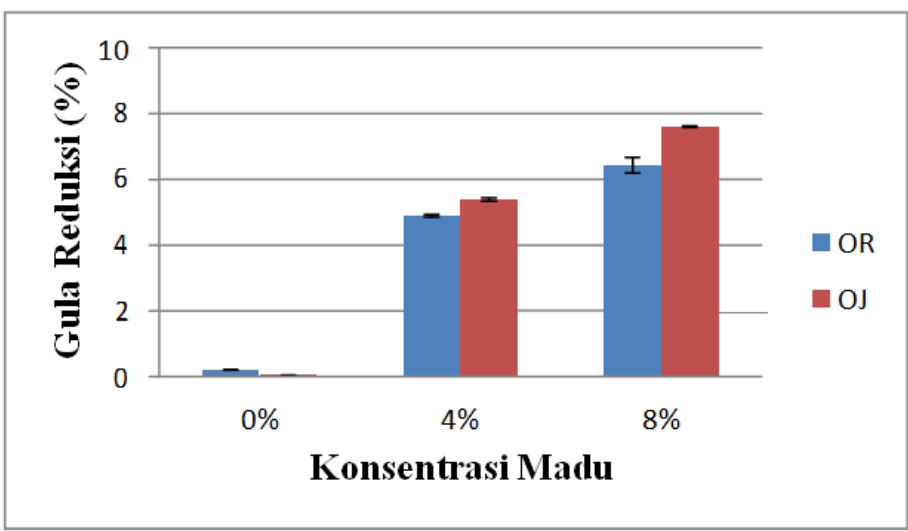

Gambar 2. Hasil uji gula reduksi $\left(\mathrm{T}_{24}\right)$ water kefir okra maduketerangan: OR

$\rightarrow$ okra rendam OJ $\rightarrow$ okra jus.

Hasil uji statistik untuk kadar gula reduksi menunjukkan variasi perlakuan okra tidak berpengaruh terhadap parameter tersebut. Hal ini dapat disebabkan karena kandungan gula seperti galaktosa lebih banyak terkonsentrasi pada lendirnya (Kumar et al., 2009) sehingga tidak ada perbedaan antara perlakuan jus dan rendam. Namun, variasi konsentrasi madu berpengaruh terhadap kadar gula reduksi. Peningkatan konsentrasi madu menyebabkan meningkatnya kadar gula reduksi water kefir okra madu. Hal ini sesuai dengan pendapat Nyimas (2004) yang menyatakan bahwa kandungan gula terbesar dalam madu adalah gula sederhana seperti fruktosa $(38,2 \%)$ dan glukosa $(31,3 \%)$.

\section{c. Total Padatan Terlarut}

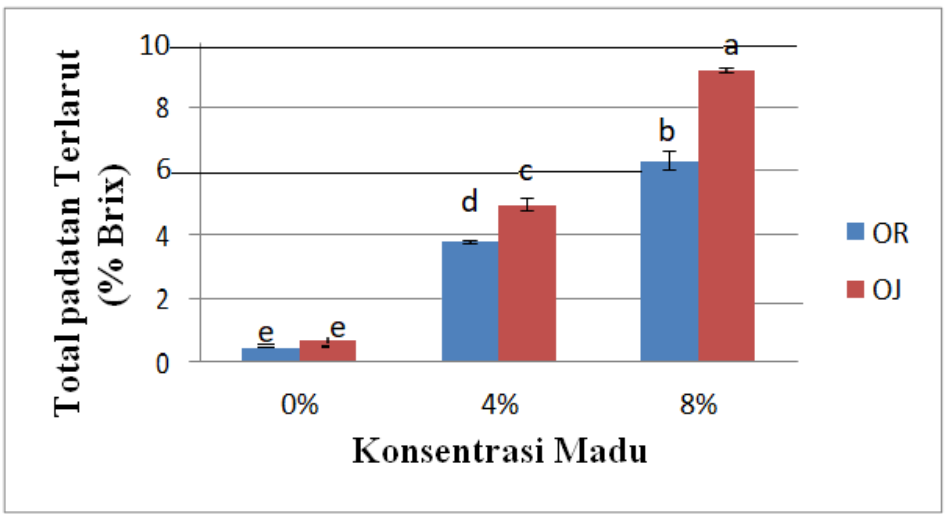

Gambar 3. Hasil uji total padatan terlarut $\left(\mathrm{T}_{24}\right)$ water kefir okra madu keterangan: OR $\rightarrow$ okra rendam OJ $\rightarrow$ okra jus.

Hasil statistik untuk total padatan terlarut menunjukkan jika variasi perlakuan okra berpengaruh terhadap parameter tersebut. Hal ini disebabkan karena saat okra dihancurkan menggunakan blender, komponen padatan terlarut pada okra seperti karbohidrat (Kumar et al., 2009) dan asam amino seperti lisin dan triptofan (Sanjeet et al., 2010) akan lebih terlarut merata di dalam air dibandingkan dengan proses perendaman. Variasi konsentrasi madu juga berpengaruh terhadap total padatan terlarut. Hal tersebut sesuai dengan pendapat Osundahusi et al. (2007) yang menyatakan bahwa kandungan gula yang tinggi berkontribusi terhadap komponen padatan terlarut yang lebih tinggi. Hasil statistikjuga menunjukkan adanya interaksi antara variasi perlakuan okra dan konsentrasi madu. Hal ini menunjukkan jika kedua 
faktor tersebut saling terkait dalam memengaruhi hasil padatan terlarut karena kedua faktor tersebut sama-sama menyumbangkan komponen padatan terlarut. Selain itu, proses fermentasi akan menghasilkan produk seperti asam laktat dan asam organik lainnya (Fardiaz, 2003). Komponen-komponen seperti asam-asam organik, asam amino, dan sisa gula tersebut akan terhitung sebagai padatan terlarut (Sintasari et al., 2014).

\section{d. Asam Laktat}

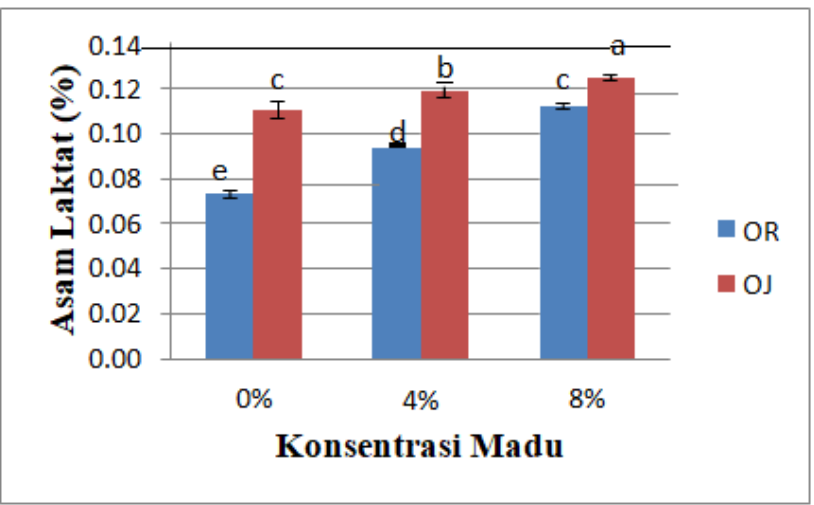

Gambar 4. Hasil uji asam laktat $\left(\mathrm{T}_{24}\right)$ water kefir okra madu keterangan: OR $\rightarrow$ okra rendam OJ $\rightarrow$ okra jus.

Hasil statistik untuk uji asam laktat menunjukkan variasi perlakuan okra berpengaruh terhadap hasil asam laktat. Hal ini disebabkan karena kandungan gula pada water kefir okra jus lebih tinggi sehingga lebih banyak substrat yang dapat dimanfaatkan oleh mikroorganisme untuk menghasilkan produk metabolit berupa asam laktat (Nehemya, 2017). Variasi konsentrasi madu juga berpengaruh terhadap hasil asam laktat. Semakin tinggi konsentrasi madu maka semakin tinggi pula kadar asam laktatnya. Hal ini menunjukkan jika BAL akan menghasilkan asam laktat yang optimal apabila substrat pada media tumbuhnya tercukupi (Syahputra, et al., 2015). Hasil uji statistik juga menunjukkan adanya interaksi antara variasi perlakuan dan konsentrasi madu. Hal tersebut menunjukkan jika kedua faktor tersebut saling terkait dalam memengaruhi kadar asam laktat karenakedua faktor tersebut sama-sama menyumbangkan nutrisi yang mampu dimanfaatkan oleh BAL untuk menghasilkan produk fermentasi berupa asam laktat.

e. $\mathbf{p H}$

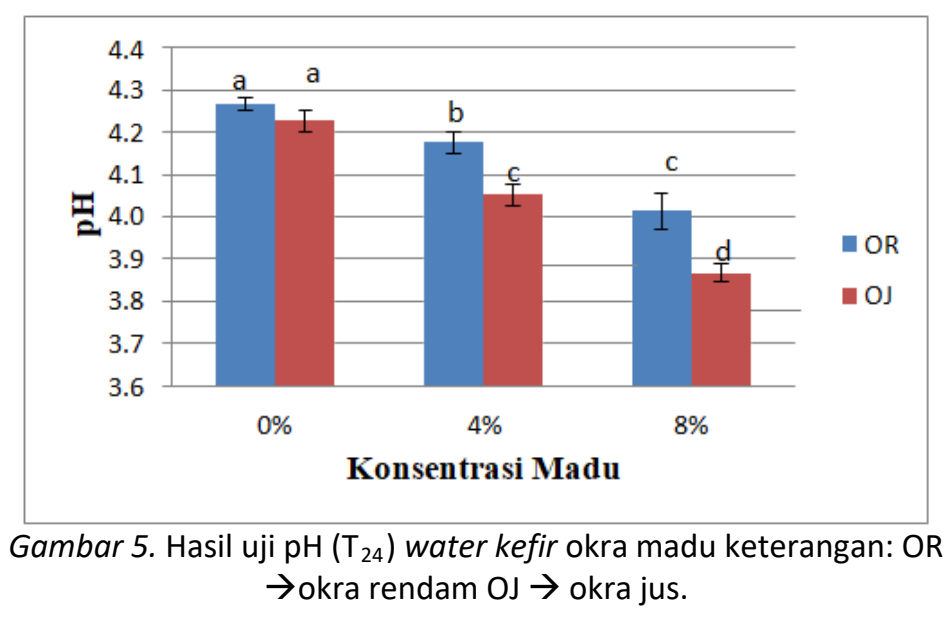

Hasil statistik untuk uji pH menunjukkan jika variasi perlakuan okra berpengaruh terhadap nilai $\mathrm{pH}$. Hal tersebut disebabkan okra dapat dijadikan substrat oleh BAL yang untuk diubah menjadi produk fermentasi berupa asam. Fermentasi yang melibatkan bakteri asam 
laktat akan ditandai dengan peningkatan jumlah asam-asam organik yang menyebabkan penurunan pH (Yusmarini \& Efendi, 2004). Semakin banyaknya asam yang dihasilkan oleh bakteri maka nilai pH akan semakin menurun (Setioningsih et al., 2004). Variasi konsentrasi madu juga berpengaruh terhadap nilai $\mathrm{pH}$. Pemberian madu berdampak pada penurunan $\mathrm{pH}$, hal tersebut dikarenakan pada madu terkandung asam-asam organik (Murugaiyan et al., 2018) yang menyebabkan nilai $\mathrm{pH}$ semakin menurun seiring bertambahnya konsentrasi madu. Selain itu, selama proses fermentasi, gula yang terkandung dalam madu juga mampu dimanfaatkan oleh BAL untuk untuk diubah menjadi asam sehingga semakin banyak asam yang dihasilkan maka semakin rendah nilai pH. Hal ini sesuai dengan pernyataan Walstra (1999) yang menyatakan kenaikan asam dalam konsentrasi rendah dapat berpengaruh terhadap laju disosiasi ion $\mathrm{H}+$ sehingga berakibat pada perubahan $\mathrm{pH}$ media. Hasil statistik juga menunjukkan jika terdapat interaksi antara variasi perlakuan okra dan konsentrasi madu. Hal ini dapat disebabkan karena kedua faktor tersebut memiliki peran yang sama sebagai subtrat yang dapat dimanfaatkan oleh BAL untuk menghasilkan produk fermentasi berupa asam yang menyebabkan nilai $\mathrm{pH}$ menurun.

\section{f. Total Asam}

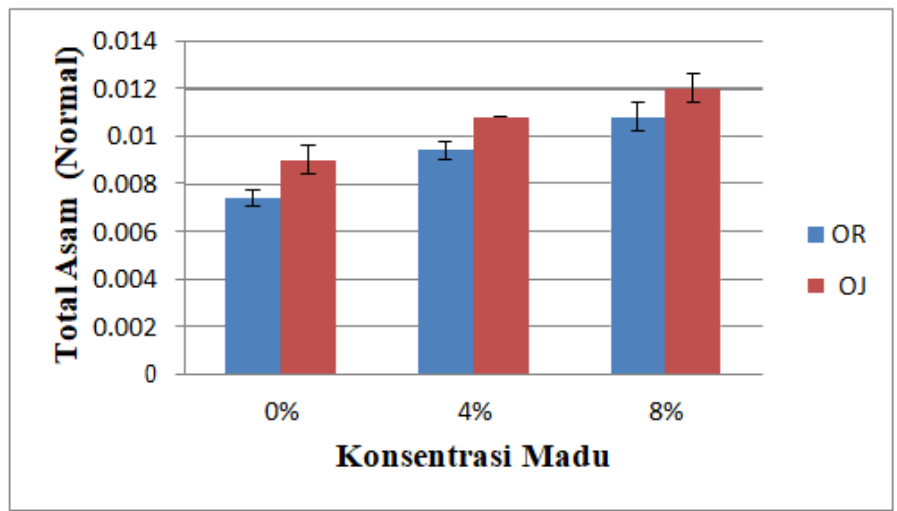

Gambar 6. Hasil uji total asam $\left(\mathrm{T}_{24}\right)$ water kefir okra madu keterangan: $\mathrm{OR} \rightarrow$ okra rendam OJ $\rightarrow$ okra jus.

Hasil uji kadar total asam menunjukkan variasi perlakuan okra berpengaruh terhadap hasil total asam. Hal ini dapat disebabkan karena perlakuan okra jus memiliki kandungan gula yang lebih tinggi dibandingkan dengan okra perlakuan rendam sehingga lebih banyak substrat yang dapat dimanfaatkan selamaproses fermentasi untuk menghasilkan produk asam seperti asam laktat, asam asetat dan asam propionate. Hal tersebut menyebabkan nilai total asam meningkat (Setioningsih et al., 2004). Variasi konsentrasi madu juga berpengaruh terhadap hasil total asam. Hal ini dapat disebabkan penambahan konsentrasi madu berdampak pada peningkatan jumlah gula yang dapat dimetabolisme oleh BAL untuk menghasilkan produk berupa asam (Setioningsih et al., 2004). Selain itu, madu juga mengadung asam-asam organik, kehadiran asam organik tersebut juga dapat menyebabkan peningkatan pada kadar total asam (Murugaiyan et al., 2018). Hasil uji statistik menunjukkan variasi perlakuan okra dan konsentrasi madu tidak memiliki interaksi. Hal tersebut mungkin terjadi karena variasi perlakuan okra dan konsentrasi madu tidak saling terkait terhadap parameter total asam. 


\section{g. Aktivitas Antioksidan}

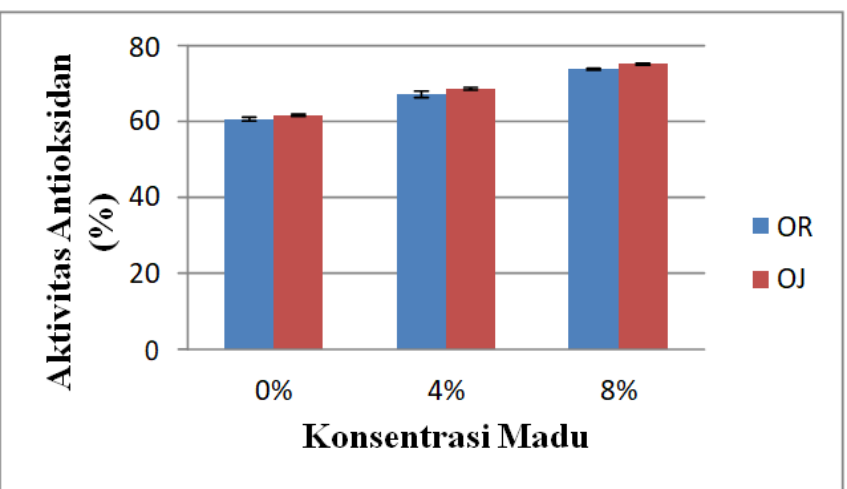

Gambar 7. Hasil uji aktivitas antioksidan $\left(\mathrm{T}_{24}\right)$ water kefir okra madu keterangan: OR $\rightarrow$ okra rendam OJ $\rightarrow$ okra jus.

Hasil statistik untuk uji aktivitas antioksidan menunjukkan jika variasi perlakuan okra berpengaruh terhadap parameter tersebut. Hal ini dapat disebabkan karena perlakuan jus menyebabkan kandungan antioksidan dalam okra seperti seperti vitamin C, vitamin E, karotenoid, dan flavonoid (Krinsky, 2001) lebih terlarut merata dibandingkan dengan perlakuan rendam. Variasi konsentrasi madu juga berpengaruh terhadap aktivitas antioksidan. Hal ini disebabkan karena pada madu mengandung sejumlah senyawa yang memiliki sifat antioksidan seperti senyawa fenolik, flavonoid, asam askorbat, karoten, vitamin E dan sebagainya (Ferreira, et al., 2009). Selain itu, madu juga berperan sebagai penyedia nutrisi untuk BAL sehingga BAL dapat menghasilkan produk fermentasi berupa asam. Proses fermentasi akan menghasilkan asam organik yang mampu memberikan ion $\mathrm{H}^{+}$pada radikal bebas, sehingga hal tersebut berdampak pada meningkatnya aktivitas antioksidan (Musdolifah, 2016). Hasil uji statistik menunjukkan jika tidak terdapat interaksi untuk variasi perlakuan okra dan konsentrasi madu. Hal tersebut mungkin terjadi karena variasi perlakuan okra dan konsentrasi madu tidak saling terkait terhadap parameter aktivitas antioksidan.

\section{h. Etanol}

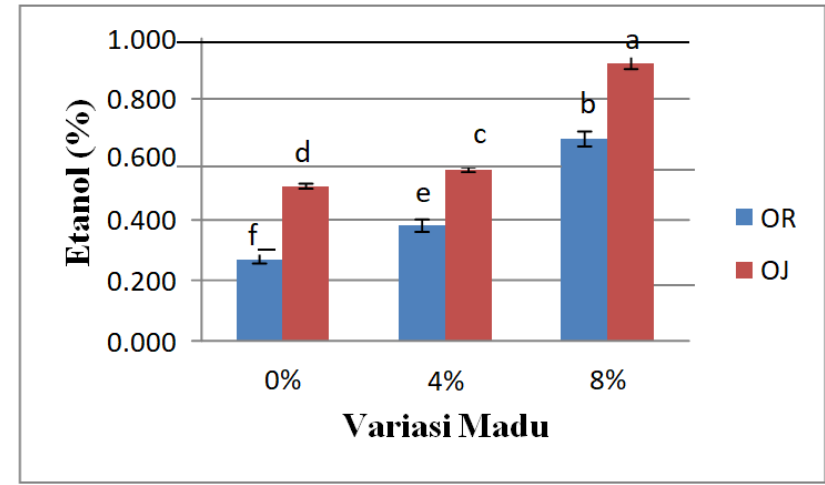

Gambar 8. Hasil uji etanol $\left(\mathrm{T}_{24}\right)$ water kefir okra madu keterangan: OR $\rightarrow$ okra rendam OJ $\rightarrow$ okra jus.

Hasil statistik untuk uji kadar etanol menunjukkan jika perlakuan okra berpengaruh terhadap parameter tersebut. Hal ini dapat disebabkan karena kandungan gula pada okra jus lebih tinggi dibandingkan dengan okra rendam sehingga lebih banyak substrat yang dapat dimanfaatkan oleh sehingga lebih banyak substrat yang dapat dimanfaatkan oleh yeast untuk menghasilkan etanol (Azizah, et al., 2012). Variasi konsentrasi madu juga berpengaruh terhadap kadar etanol. Hal tersebut dikarenakan madu bertindak sebagai penyedia gula yang selanjutnya akan difermentasi oleh yeast menjadi etanol (Azizah, et al., 2012). Hasil uji statistik menunjukkan jika variasi perlakuan okra dan konsentrasi madu memiliki interaksi. Hal tersebut 
disebabkan karena kedua faktor tersebut sama- sama berperan sebagai penyedia gula yang dapat dimanfaatkan oleh yeast untuk menghasilkan etanol.

\section{i. Total BAL}

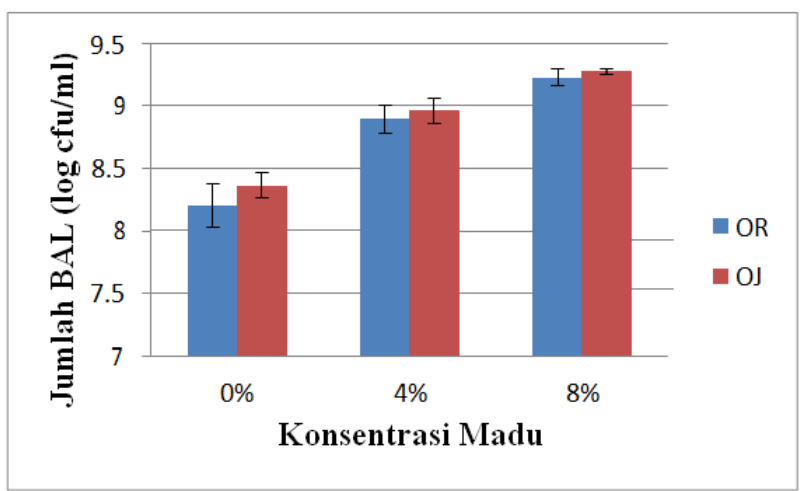

Gambar 9. Hasil uji total BAL $\left(\mathrm{T}_{24}\right)$ water kefir okra maduketerangan: $\mathrm{OR} \rightarrow$ okra rendam OJ $\rightarrow$ okra jus.

Hasil uji total BAL menujukkan jika variasi perlakuan okra tidak berpengaruh terhadap total BAL (lampiran 10). Banyak faktor yang memengaruhi pertumbuhan mikroorganisme mulai dari kebutuhan karbon, vitamin, nitrogen hingga mineral (Buckle, et al., 2007). Variasi perlakuan okra yang tidak memberikan pengaruh menunjukkan jika perlakuan jus dan rendam memiliki efek yang sama dalam pemenuhan kebutuhan nutrisi BAL sehingga kedua perlakuan tersebut tidak berpengaruh terhadap total BAL. Namun, variasi konsentrasi madu berpengaruh terhadap total BAL (lampiran 10). Hal ini dapat disebabkan karena gula merupakan sumber energi yang baik bagi mikroorganismedalam proses perkembangbiakan (Herawati \& Wibawa, 2011). Pada gambar 4.9 dapat dilihat jika semakin tinggi penambahan madu, semakin tinggi pula total BAL. Kecepatan pertumbuhan dan viabilitas BAL pada proses fermentasi ditentukan oleh kesesuaian dan kandungan nutrisi yang ada dalam media fermentasi (Nisa, et al., 2008). Hasil uji statistik menunjukkan tidak adanya interaksi antara variasi perlakuan okra dan konsentrasi madu. Hal ini dapat terjadi karena faktor yang mempengaruhi total BAL hanyalah konsentrasi madu sehinggatidak terjadi interaksi antara faktor perlakuan okra dan konsentrasi madu.

\section{j. Total Yeast}

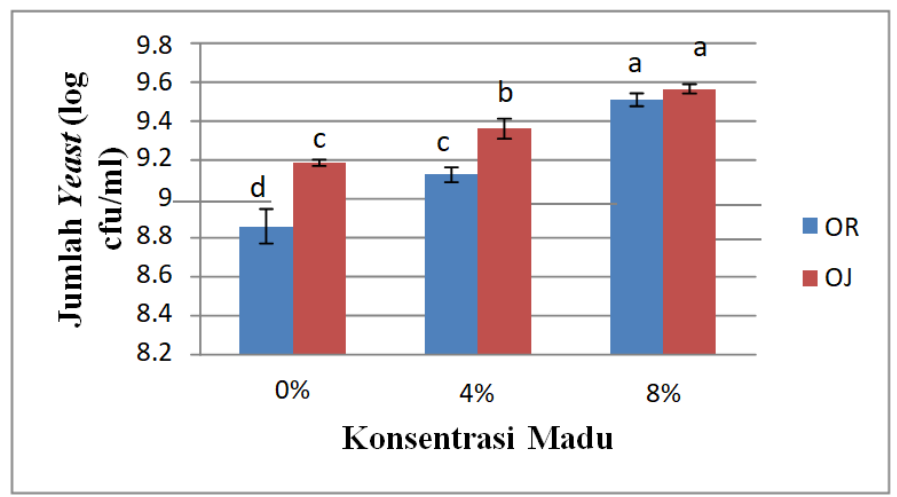

Gambar 10. Hasil uji total yeast $\left(\mathrm{T}_{24}\right)$ water kefir okra madu keterangan: OR $\rightarrow$ okra rendam OJ $\rightarrow$ okra jus.

Hasil uji total yeast menunjukkan jika variasi perlakuan okra berpengaruh terhadap parameter tersebut (lampiran 11). Pada gambar 4.10 dapat dilihat jika perlakuan jus memiliki total yeast yang lebih tinggi dibandingkan dengan perlakuan rendam. Hal ini dapat disebabkan karena kandungan gula pada okra jus lebih tinggi dibandingkan dengan okra rendam (gambar 4.1) sehingga ketersediaan nutrisi bagi yeast lebih tercukupi. Variasi konsentrasi madu juga 
berpengaruh terhadap total yeast (lampiran 11). Pada gambar 4.10 dapat dilihat jika semakin tinggi konsentrasi madu, semakin tinggi pula total yeast. Herawati \& Wibawa (2011) menyatakan bahwa gula (sukrosa, glukosa, laktosa dan fruktosa), selain sebagai sumber rasa manis juga merupakan sumber energi yang baik bagi mikroorganisme dalam proses perkembangbiakan. Hasil uji statistik juga menunjukkan jika terdapat interaksi antara kedua faktor tersebut (lampiran 11). Hal ini dapat disebabkan karena kedua faktor tersebut saling terkait dalam menyumbangkan nutrisi untuk perkembangbiakan yeast.

\section{k. Uji Warna}

Tabel 1

Hasil Uji Warna Water Kefir Okra Madu

\begin{tabular}{|c|c|c|c|c|}
\hline \multicolumn{5}{|c|}{ T24 } \\
\hline \multirow{2}{*}{ Variasi Okra } & \multirow{2}{*}{ Parameter } & \multicolumn{3}{|c|}{ Variasi Madu } \\
\hline & & $0 \%$ & $4 \%$ & $8 \%$ \\
\hline \multirow{3}{*}{$\begin{array}{c}\text { Okra } \\
\text { Rendam }\end{array}$} & $\mathrm{L}$ & 18,7 & 17,3 & 16,6 \\
\hline & a & $-0,3$ & $-0,1$ & 0.1 \\
\hline & b & 0,1 & 0,3 & 0,7 \\
\hline \multirow[t]{3}{*}{ Okra Jus } & L & 17,6 & 16,1 & 13,3 \\
\hline & a & -1 & $-0,8$ & $-0,1$ \\
\hline & $b$ & $-0,1$ & 0,2 & 0,7 \\
\hline
\end{tabular}

Terdapat tiga parameter pada hasil uji warna menggunakan color reader yaitu $L^{*}$, a* dan $b^{*}$. $L^{*}$ mendeskripsikan tingkat kecerahan sampel. Semakin tinggi nilai $L$ maka tingkat kecerahan sampel semakin tinggi. a* mendeskripsikan warna merah atau hijau, yakni nilai a+ berarti cenderung ke warna merah, sedangkan nilai a- cenderung ke warna hijau. b* mendeskripsikan warna kuning atau biru, di mana nilai $b+$ berarti cenderung ke warna kuning, sedangkan nilai b- cenderung ke arah biru. Pada Tabel 1, pemberian madu berdampak pada menurunnya tingkat kecerahan $\left(L^{*}\right)$. Hal serupa juga terjadi untuk kefir okra jus, yakni tingkat kecerahan semakin turun seiring dengan meningkatnya konsentrasi madu. Namun, apabila dibandingkan dengan kefir okra rendam, kefir okra jus memiliki tingkat kecerahan yang lebih kecil. Hal tersebut mungkin terjadi karena warna dasar dari water kefir okra rendam lebih bening. Hasil tersebut dapat dikaitkan dengan hasil uji total padatan terlarut, yakni semakin tingginya komponen padatan terlarut, maka akan berdampak pada semakin turunnya tingkat kecerahan warna. Pendapat ini didukung oleh Oktavia (2016) yang menyatakan bahwa senyawa-senyawa terlarut berupa senyawa fitokimia yang bersifat polar, karbohidrat, protein, dan mineral dapat meningkatkan tingkat kekeruhan. Selanjutnya, nilai all pada kefir okra jus lebih negatif dibandingkan dengan kefir okra rendam. Hal tersebut dikarenakan nilai -enderung ke arah hijau, di mana pada kefir okra jus terkandung klorofil yang cukup tinggi yang banyak ditemui pada sayur-sayuran (Astawan, 2004). Nilai bll pada water kefir okra madu cenderung ke arah positif (kuning) yang menandakan penambahan konsentrasi madu berpengaruh terhadap warna kuning dari water kefir okra madu. Menurut Oktavia (2016) madu memiliki warna dasar kuning kecoklatan. 


\section{Uji Mikroba Kontaminan Water Kefir Okra Madu}

Tabel 2

Hasil Uji Mikroba Kontaminan Coliform dan Salmonella sp

\begin{tabular}{|c|c|c|c|c|}
\hline \multicolumn{5}{|c|}{ Coliform } \\
\hline \multirow{2}{*}{$\begin{array}{c}\text { Variasi Okra } \\
\text { Madu }\end{array}$} & \multicolumn{2}{|c|}{ Tabung Hasil Positif } & & \multirow{2}{*}{ MPN/100ml } \\
\hline & LB $3 x(10 \mathrm{ml})$ & LB 1x (1 ml) & $\begin{array}{c}\text { LB } 1 \times(0,1 \\
\mathrm{ml})\end{array}$ & \\
\hline Okra Rendam 0\% & 0 & 0 & 0 & 0 \\
\hline Okra Rendam 4\% & 0 & 0 & 0 & 0 \\
\hline Okra Rendam 8 \% & 0 & 0 & 0 & 0 \\
\hline Okra Jus 0\% & 0 & 0 & 1 & 3 \\
\hline Okra Jus 4\% & 0 & 0 & 0 & 0 \\
\hline Okra Jus $8 \%$ & 2 & 0 & 0 & 9 \\
\hline \multicolumn{5}{|c|}{ Salmonella sp. } \\
\hline \multirow{2}{*}{$\begin{array}{c}\text { Variasi Okra } \\
\text { Madu }\end{array}$} & \multicolumn{2}{|c|}{ Tabung Hasil Positif } & & \multirow{2}{*}{ Hasil } \\
\hline & XLD & $\mathrm{HE}$ & BSA & \\
\hline Okra Rendam 0\% & Negatif & Negatif & Negatif & Negatif \\
\hline Okra Rendam 4\% & Negatif & Negatif & Negatif & Negatif \\
\hline Okra Rendam $8 \%$ & Negatif & Negatif & Negatif & Negatif \\
\hline Okra Jus 0\% & Negatif & Negatif & Negatif & Negatif \\
\hline Okra Jus 4\% & Negatif & Negatif & Negatif & Negatif \\
\hline Okra Jus 8\% & Negatif & Negatif & Negatif & Negatif \\
\hline
\end{tabular}

Pada Tabel 2, hasil uji kontaminan coliform didapatkan hasil positif untuk 1 tabung LB $1 \mathrm{x}$ kuat $(0,1 \mathrm{ml})$ water kefir okra jus madu $0 \%$ dan 2 tabung positif KB $3 x$ kuat $(10 \mathrm{ml})$ water kefir okra jus madu $8 \%$. Jumlah MPN untuk water kefirokra jus madu $0 \%$ adalah $3 / 100 \mathrm{ml}$, sedangkan untuk water kefir okra jus madu $8 \%$ adalah $9 / 100 \mathrm{ml}$. Sampel dengan variasi lainnya tidak didapatkan hasil positif padasemua tabung. Hasil tersebut sesuai dengan standar SNI, di mana standar minimal SNI untuk kontaminan coliform adalah 10/ml (Badan Standarisasi Nasional, 2009) sehingga minuman water kefir okra madu tersebut dikatakan masih layak untuk dikonsumsi. Adanya coliform diduga berasal dari penggunaan media LB yang telah terkontaminasi sebelumnya.

Pada hasil uji Salmonella sp. tidak didapatkan ciri dari bakteri Salmonella sp. yang tumbuh pada media XLD, HE dan BSA. Pada media XLD, Salmonella sp. akan menunjukkan bentuk koloni berwarna merah dengan inti hitam, pada media $\mathrm{HE}$, Salmonella sp. akan menunjukkan bentuk koloni hijau kebiruan, dan pada media BSA akan membentuk warna hitam. Hasil uji tersebut dapat dikatakan memenuhi standar SNI yang menyatakan bahwa kontaminan Salmonella sp. harus negatif (Badan Standarisasi Nasional, 2009). 


\section{Uji Organoleptik Water Kefir Okra Madu}

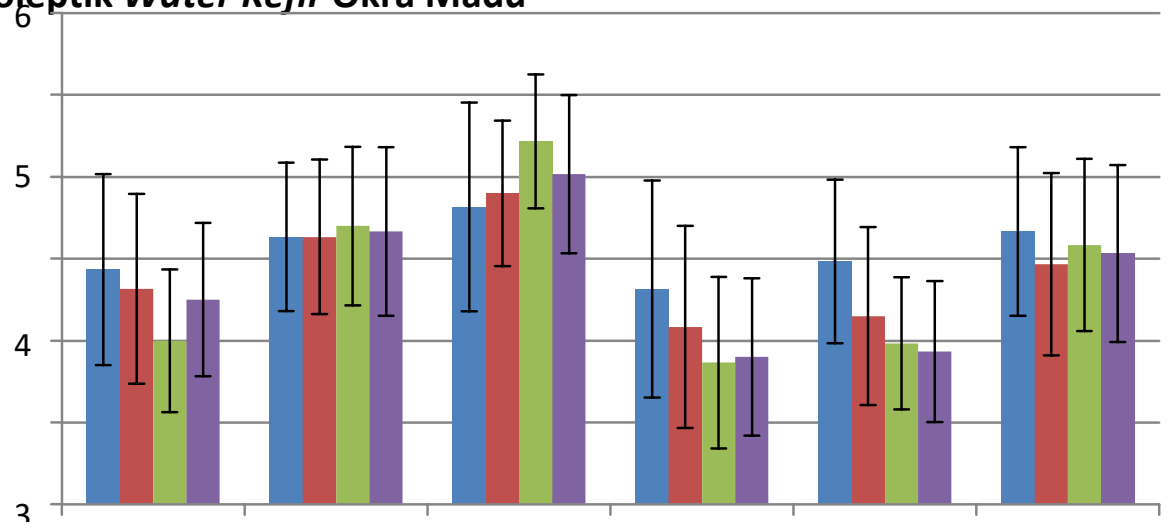

Gambar 11. Hasil uji organoleptik rating hedonik water kefir okra madu.

$$
\begin{aligned}
\text { Keterangan : } & \text { Skor } 1 \rightarrow \text { Tidak Suka } \\
& \text { Skor } 2 \rightarrow \text { Kurang Suka } \\
& \text { Skor } 3 \rightarrow \text { Cukup Suka } \\
& \text { Skor } 4 \rightarrow \text { Suka } \\
& \text { Skor } 5 \rightarrow \text { Sangat Suka }
\end{aligned}
$$

Uji Organoleptik rating hedonik menggunakan empat parameter uji yaitu warna, aroma, rasa dan aftertaste. Hasil statistik untuk uji warna menunjukkan terdapat pengaruh antara variasi perlakuan okra dan konsentrasi madu terhadap parameter warna. Pada gambar 11, warna dari water kefir okra rendam madu 8\% paling disukai oleh panelis dengan deskripsi hasil yaitu cukup suka, selanjutnya diikuti oleh water kefir okra jus dengan madu $8 \%$. Warna yang paling tidak disukai oleh panelis adalah warna dari water kefir okra jus madu $0 \%$. Hal tersebut menunjukkan jika tingkat kesukaan panelis pada uji warna bergantung pada warna dari intensitas madu karena semakin tinggi konsentrasi madu, maka semakin tinggi tingkat kesukaan panelis terhadap uji warna.

Hasil statistik untuk uji aroma menunjukkan jika variasi perlakuan okra dan konsentrasi madu berpengaruh. Water kefir okra rendam madu $8 \%$ memiliki tingkat kesukaan paling tinggi dengan deskripsi hasil adalah cukup suka, diikuti oleh water kefir okra rendam $4 \%$ dan water kefir jus $8 \%$ sedangkan sampel yang paling tidak disukai adalah water kefir okra jus $0 \%$. Pada Gambar 11, konsentrasi madu memengaruhi kesukaan panelis pada uji aroma. Semakin tinggi konsentrasi madu yang diberikan maka semakin tinggi pula tingkat kesukaan panelis pada parameter aroma ini. Jika dibandingkan water kefir okra rendam dan water kefir okra jus pada konsentrasi madu yang sama, didapatkan hasil jika waterkefir okra jus lebih tidak disukai. Hal tersebut mungkin dikarenakan aroma yang khas dari okra jus yang menyebabkan banyak panelis kurang menyukainya dibandingkan dengan aroma dari okra rendam yang tidak memiliki aroma (Pratiwi, 2016).

Hasil statistik untuk uji rasa menunjukkan jika variasi perlakuan okra dan konsentrasi madu berpengaruh. Water kefir okra rendam $8 \%$ memiliki tingkat kesukaan paling tinggi dengan deskripsi hasil adalah suka. Hasil yang paling tidakdisukai adalah water kefir okra jus 0\% Pada Gambar 11, konsentrasi madu memengaruhi tingkat kesukaan panelis pada parameter rasa. Semakin tinggi konsentrasi madu, semakin tinggi kesukaan panelis. Hal tersebut dikarenakan semakin tinggi konsentrasi madu berdampak pada semakin manisnya rasa dari water kefir okra madu. Apabila dibandingkan antara water kefir okra rendam dan jus dengan tingkat konsentrasi pada yang sama, maka didapatkan hasil water kefir okra rendam lebih disukai oleh panelis. Hal tersebut dapat terjadi karena pada water kefir okra rendam, rasa yang terbentuk lebih ke arah netral atau hambar (Uzma, 2013), sedangkan pada water kefir okra jus memiliki rasa yang sedikit pahit.

Hasil statistik untuk uji aftertaste menunjukkan jika variasi perlakuan okra dan konsentrasi madu berpengaruh. Pada gambar 11 , water kefir okra rendam $8 \%$ memiliki tingkat 
kesukaan panelis yang paling tinggi dengan deskripsi hasil yaitu suka. Pada water kefir okra jus $0 \%$ memiliki tingkat kesukaan panelis yang paling rendah. Konsentrasi madu memengaruhi tingkat kesukaan panelis, semakin tinggi konsentrasi madu maka semakin tinggi pula tingkat kesukaan panelis. Apabila dibandingkan antara water kefir okra rendam dan water kefir okra jus pada tingkat konsentrasi madu yang sama. Water kefir okra rendam lebih disukai daripada kefir okra jus pada parameter aftertaste. Hal ini berkaitan erat dengan hasil uji rasa, rasa dari kefir okra rendam cenderung ke rasa hambar (Uzma, 2013) sehingga hal tersebut mungkin menciptakan aftertaste yang lebih disukai dibandingkan dengan rasa dari kefir okra jus yang cenderung pahit.

Tabel 3

Hasil Uji Deskripsi Skala Terstruktur Water Kefir Okra Rendam 8\%

\begin{tabular}{cc}
\hline Parameter & Deskripsi \\
\hline Warna & Kuning Muda \\
Aroma (asam) & Kurang Asam \\
Rasa (manis) & Cukup Manis \\
Rasa (alkohol) & Kurang \\
& Beralkohol \\
Rasa (asam) & Kurang Asam \\
Aftertaste & Tidak Pahit \\
(pahit) & \\
\hline
\end{tabular}

Hasil statistik uji organoleptik rating hedonik menunjukkan jika terdapat beda signifikan untuk semua parameter (warna, aroma, rasa, dan aftertaste). Dari uji tersebut, water kefir okra rendam $8 \%$ merupakan perlakuan yang paling disukai oleh panelis dengan karakteristik yaitu warna kuning muda, aroma kurang asam, rasa cukup manis, rasa kurang beralkohol, rasa kurang asam, dan aftertaste tidak pahit.

\section{Uji Penentuan Hasil Terbaik Metode Indeks Efektivitas}

Pada penentuan hasil terbaik menggunakan metode Indeks Efektivitas didapatkan water kefir okra rendam $8 \%$ merupakan perlakuan terbaik. Hasil penentuan terbaik didapatkan dari jumlah nilai hasil ( $\mathrm{Nh}$ ) untuk uji fisikokimia dan nilai hasil (Nh) untuk uji organoleptik. Nilai yang paling tinggi menunjukkan hasil tersebut merupakan hasil terbaik dari hasil uji fisikokimia dan organoleptik. Hasil uji penentuan hasil terbaik dapat dilihat pada tabel 4.

Tabel 4

Uji Penentuan Hasil Terbaik Menggunakan Metode Indeks Efektivitas

\begin{tabular}{lcccc}
\hline Variasi & Organoleptik & Fisikokimia & Jumlah & Ranking \\
\hline OR 8\% & 0,6 & 0,29 & 0,89 & 1 \\
OJ 8\% & 0,3 & 0,4 & 0,7 & 2 \\
OR 4\% & 0,36 & 0,17 & 0,53 & 3 \\
OJ 4\% & 0,06 & 0,3 & 0,36 & 4 \\
OJ 0\% & 0 & 0,16 & 0,16 & 5 \\
OR 0\% & 0,13 & 0 & 0,13 & 6 \\
\hline
\end{tabular}

Penentuan perlakuan terbaik menggunakan metode indeks efektivitas (DeGarmo, et al., 1984). Parameter yang diukur adalah total BAL, total yeast dan total asam yang mengacu pada produk fermentasi sejenis yaitu yoghurt (SNI, 2009) dan kefir susu (Codex, 2003). Bobot penilaian diambil dengan persentase $40 \%$ untuk uji fisikokimia dan $60 \%$ untuk uji organoleptik. Hasil perhitungan menggunakan metode ini menunjukkan jika water kefir okra rendam $8 \%$ merupakan hasil terbaik dengan total skor sebesar 0,89. 


\section{SIMPULAN}

Berdasarkan hasil penelitian water kefir okra madu, maka dapat ditarik kesimpulan sebagai berikut: (a) Pada hasil uji fisikokimia, variasi perlakuan okra dan konsentrasi madu berpengaruh terhadap parameter gula total, total padatan terlarut, total asam, kadar asam laktat, $\mathrm{pH}$, aktivitas antioksidan,kadar etanol, total BAL dan total yeast. Variasi perlakuan okra dan konsentrasi madu jugaberinteraksi terhadap parameter total padatan terlarut, kadar asam laktat, pH, kadar etanol, dan total yeast; (b) Pada hasil uji organoleptik, variasi perlakuan okra dan konsentrasimadu berpengaruh terhadap parameter uji warna, aroma, rasa dan aftertaste; (c) Pada penentuan perlakuan terbaik, water kefir okra rendam madu $8 \%$ merupakan hasil terbaik dari hasil uji fisikokimia dan organoleptik.

\section{PUSTAKA ACUAN}

Astawan, M. (2004). Khasiat dan Manfaat Buah Paprika. http://cybermed.cbn.net.id diakses pada 19 Desember 2019

Azizah, N., A. N Al-Baarri., \& S. Mulyani. (2012). Pengaruh lama fermentasi terhadap kadar alkohol, $\mathrm{pH}$, dan produksi gas pada proses fermentasi bioetanol dari whey dengan substitusi kulit nenas. Jurnal Aplikasi Teknologi Pangan. Vol 1 (2): 72-77

Badan Standardisasi Nasional. (2009). SNI Yoghurt . Badan Standardisasi Nasional. Jakarta

Buckle, K.A., R.A. Edward., G.H. Fleet.,\& M. Wooton. (2007). Ilmu Pangan. UI Press. Jakarta

Codex Alimentarius Commission. (2003). Codex Standard for Fermented Milks: Codex STAN 243. FAO/WHO Food Standards.

De Garmo, E.D, W.G. Sullivan., \& J. R. Canada. (1984). Engineering Economis. Mc Millan Publishing Company. New York.

Farnworth, E. \& Mainville, I. (2008). Kefir-A Fermented Milk Product. In Handbook of Fermented Functional Foods. Second Edition Farnworth Edward R.Broken Sound Parkway NW, Taylor \& Francis Group, LLC. pp89-127.

Ferreira, I.C.F.R., Aires, E., Barreira, J.C.M., \& Estevinho, L.M. (2009). Antioxidant Activity of Portuguese Honey Samples: Different Contributions of the Entire Honey and Phenolic Extract. Food Chemistry. 114(4), 1438-1443.

Gulitz, A., Stadie, J., Wenning, M.,Ehrmann, M. A., \& Vogel, R. F. (2011). The Microbial Diversity of Water Kefir. International Journal of Food Microbiology 151(3): 284-288.

Herawati D.A. \& A.A. Wibawa. (2011). Pengaruh konsentrasi susu skim dan waktu fermentasi terhadap hasil pembuatan soyghurt. Universitas Setia Budi : Surakarta. Jurnal Ilmiah Teknik Lingkungan vol. 1(2): 48-50.

Krinsky, N. I. (2001). Carotenoids as antioxidants.Nutrition 17, 815-817.

Kumar, R., Patil, MB., Patil, SR., \& Paschapur, MS. (2009). Evaluation of Abelmoschus esculentus mucilage as paracetamol suspension. Intl. J. Pharm. Tech. Res. 1:658-665.

Murugaiyan, Senthilkumar., Subbaralayu, Mohankumar., \& Srivinasan. (2018).

M.R Isolation, Characterization and Identification of Probiotic Lactic Acid Bacteria (LAB) from Honey Bees. International Journal of Current Microbiology and Applied Sciences ISSN: 2319-7706 Volume $7: 04$

Musdolifah \& Elok Zubaidah. (2016). Studi Aktivitas Antioksidan Kefir Teh Daun Sirsak Dari Berbagai Merk Dipasaran. Malang: FTP Universitas Brawijaya.

Nehemya, Devryna., Lubis, Linda Masniary., \& Nainggolan, Rona. J. (2017). Pengaruh Konsentrasi Gula Merah dan Konsentrasi Starter Terhadap Mutu Minuman Sinbiotik Sari Buah Sukun. Jurnal Rekayasa Pangan, Vol.5 No. 2

Nisa F.C., J. Kusnadi., \& Crisnasari. (2008). Viabilitas dan deteksi subletal bakteri probiotik pada susu kedelai fermentasi instan metode pengeringan beku (kajian jenis isolate dan konsentrasi sukrosa sebagai krioprotektan). Jurnal Teknologi Pertanian volume 9(1): 40-51.

Nyimas, Farisa Nadhilla. (2014). The Activity Of Antibacterial Agent of Honey Against Staphylococcus aureus. Journal Majority Vol 3 No.7 
Oktavia, Carolina Anggraeni., Paini, Sri Widyawati., \& T. Dwi Wibawa Budianta. (2016). Pengaruh Konsentrasi Madu Terhadap Sifat Fisikokimia dan Sifat Organoleptik Minuman Beluntas -Teh Hitam Dengan Perbandingan 25:75\% (B/B) . Univeristas Widya Mandala : Surabaya

Osundahunsi, O, F., Amosu, D., \& B.O.T. Ifesan. (2007). Quality Evaluation and Acceptability of Soy-yoghurt with Different Colours and Fruit Flavours. American Journal of Food Technology. 2: 273-280.

Pratiwi, Kurnia Intan., Mohammad, Abbas Zaini., \& Nazaruddin. (2016). Pengaruh Konsentrasi Gel Buah Okra (Abelmoschus esculentus L.) Terhadap Mutu Es Krim Campuran Susu Sapi dan Susu Kedelai. Jurnal Ilmu dan Teknologi Pangan Vol 2 No. 2

Rossetto, M., Vanzani, P., Mattivi, F., Lunelli, M., Scarpa, M., \& Rigo, A. (2002). Synergistic antioxidant effect of catechin and malvidin 3-glucoside on free radical-initiated peroxidation of linoleic acid in micelles. Archives of Biochemistry and Biophysics 408, 239-245.

Sabil, Syahriana. (2015). Pasteurisasi High Temperature Short Time (HTST) Susu Terhadap Listeria monocytogenes Pada Penyimpanan Refrigerator. Universitas Hasanuddin : Makassar

Sabitha, V., Ramachandran, S., Naveen, K.R., \& Panneerselvam, K. (2011). Antidiabetic And Antihyperlipidemic Potential Of Abelmoschus

Esculentus(L.) Moench. In Streptozotocin-Induced Diabetic Rats. J Pharm Bioallied Sci. 3(3): 397-402.

Sanjeet K., Sokona D., Adamou H., Alain R., Dov P., \& Christophe, K. (2010). Okra (Abelmoschus spp.) in West and Central Africa: Potential and progress on its improvement. African Journal of Agricultural Research Vol. 5(25), pp. 3590-3598.

Setioningsih, E., Setyaningsih, R., \& Susilowati, A. (2004). Pembuatan Minuman Probiotik dari Susu Kedelai dengan Inokulum Lactobacillus casei, Lactobacillus plantarum, dan Lactobacillus acidophillus. Bioteknologi 1 (1): 1-6.

Sintasari., Rinelda, Ayu., Joni, Kusnadi., \& Dian, Widya Ningtyas. (2014). Pengaruh Penambahan Konsentrasi Susu Skim Dan Sukrosa Terhadap Karakterisik Minuman Probiotik Sari Beras Merah. Jurnal Pangan dan Agroindustri Vol.2 No.3 p.65-7. Malang: Universitas Brawijaya.

Syahputra, Ade., Usman, Pato., \& Evy, Rossi. (2015). Variasi Penambahan Sukrosa Terhadap Mutu Cocoghurt Menggunakan Entercoccus faecalis Up-11 yang Diisolasikan dari Tempoyak. Jom Faperta Vol. 2 No.1

Usmiati, Sri. (2007). Kefir, Susu Fermentasi dengan Rasa Menyegarkan. Bogor: Balai Besar Penelitian dan Pengembangan Pascapanen Pertanian.

Uzma, Farooq., Rishabha, Malviya \& Pramod, Kumar Sharma. (2013). Extraction and Characterization of Okra Mucilage as Pharmaceutical Excipient. Academic Journal of Plant Sciences 6 (4): 168-172

Walstra, P., Geurts, T.J., Noomen, A., Jellema, A., \& Boekel, M.A.J.S. (1999). Dairy Technology. Principless of Milk Properties and Processes. New York: Marcell Dekker.

Yusmarini \& Efendi. (2004). Evaluasi Mutu Soygurt yang dibuat dengan Penambahan beberapa Jenis Gula. Jurnal Natur Indonesia 6:2, 104-110 